\title{
Memorias de un sueño: autobiografía visual de un pasado reciente en Colombia*
}

\section{Tatiana Cuéllar Torres**}

Esta investigación en artes es asumida como parte de un proceso de transformación cultural, porque relaciona el yo con el nosotros en el campo de las artes vivas y visuales para ampliar la mirada sobre las diferentes visiones que se tienen de la guerra, la violencia y el conflicto armado en el imaginario colectivo colombiano. El objetivo principal es la creación de un dispositivo poético-político que contribuya a las acciones críticas actuales y trabaje con la noción de desaparición forzada en el conflicto armado colombiano en la década de los ochenta. En este dispositivo, se recogen el relato de vida de un exactivista del M-19 en Colombia, documentos institucionales y testimonios familiares a través de entrevistas narrativas, abordados desde el género de la autobiografía dentro de un proceso creativo propio de la producción artística contemporánea. Esta puesta en escena relaciona tres actos de un sujeto político en conflicto: el acto de la memoria, el acto político en sí y el acto artístico. Además de la exposición de dos vectores de la invisibilidad y la desaparición forzada, enmarcados en la realidad social de la violencia en Colombia en el contexto familiar y de las guerrillas armadas. Los resultados esperados son el retorno al testimonio de un acontecimiento familiar para remontar la memoria desde un territorio flexible que dé lugar a un desplazamiento en el discurso histórico y artístico sobre la violencia en Colombia.

Palabras clave: memoria, escenografía, autobiografía, práctica artística, espacio familiar, desaparición doi 10.11144/javeriana.mavae16-1.mdus

Fecha de recepción: 19 de junio de 2020

Fecha de aceptación: 16 de octubre de 2020

Disponible en línea: 1 de enero de 2021

* Artículo de investigación.

** Diseñadora gráfica por el Instituto Departamental de Bellas Artes, magíster en Artes Visuales por la Universidad Nacional Autónoma de México, con orientación en comunicación y diseño gráfico, y doctoranda en Arte: Producción en Investigación de la Universidad Politécnica de Valencia.

ORCID: 0000-0003-0878-7680

Correo: tatiana.cuellar@correounivalle.edu.co

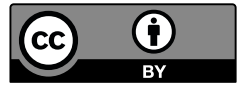




\section{Memories of a Dream: Visual Autobiography of a Recent Past in Colombia}

This research in arts is assumed as part of a process of cultural transformation, because it relates the / with the we in the field of living and visual arts to expand the view on the different visions of war, violence and armed conflict in the Colombian collective imagination. The main objective is to create a poetic-political device that contributes to current critical actions and works with the notion of forced disappearance in the Colombian armed conflict in the 1980s. In this device, the life story of a former activist of the M-19t in Colombia, institutional documents, and family testimonies are collected through narrative interviews, approached from the genre of autobiography within a creative process typical of contemporary artistic production. This staging relates three acts of a political subject in conflict: the act of memory, the political act itself, and the artistic act. In addition to the exhibition of two vectors of invisibility and forced disappearance, framed in the social reality of violence in Colombia in the context of the family and the armed guerrillas. The expected results are a return to the testimony of a family event to trace the memory from a flexible territory that leads to a displacement in the historical and artistic discourse on violence in Colombia.

Keywords: memory, scenography, autobiography, artistic practice, family space, disappearance.

\section{Memórias de um sonho: autobiografia visual de um passado recente na Colômbia}

Esta pesquisa nas artes é assumida como parte de um processo de transformação cultural, porque relaciona o eu com o nós no campo das artes vivas e visuais para ampliar o olhar sobre as diferentes visões que se têm da guerra, da violência e do conflito armado no imaginário coletivo colombiano. 0 objetivo principal é a criação de um dispositivo poético-político que contribua com as ações críticas atuais e trabalhe com a noção de desaparecimento forçado no conflito armado colombiano na década dos anos oitenta. Nesse dispositivo, a história de vida de um ex-ativista do M-19 na Colômbia, documentos institucionais e depoimentos familiares são coletados por meio de entrevistas narrativas, abordadas a partir do gênero da autobiografia dentro de um processo criativo próprio da produção artística contemporânea. Esta encenação relaciona três atos de um sujeito político em conflito: 0 ato da memória, 0 ato político em si e 0 ato artístico. Além da exposição de dois vetores da invisibilidade e do desaparecimento forçado, enquadrados na realidade social da violência na Colômbia no contexto da família e das guerrilhas armadas. Os resultados esperados são o retorno ao testemunho de um acontecimento familiar para reconstruir a memória a partir de um território flexível que dê origem a um deslocamento no discurso histórico e artístico sobre a violência na Colômbia.

Palavras-chave: memória, cenografia, autobiografia, prática artística, espaço familiar, desaparecimento. 
Introducción

> Esta investigación artística hace parte de la tesis doctoral titulada Memorias de un sueño: una cadena infinita de afectos para hacernos invisibles a la muerte, que ha sido pensada para un territorio transdisciplinar que propone un dispositivo escénico que apuesta por el desarrollo de lenguajes propios, a partir del potencial del audiovisual, la performatividad y la instalación. Parte de la duda frente a un hecho familiar y la idea utópica de la responsabilidad política que tienen los hijos frente al pasado, para convertirlo en este caso en un acto performativo.

Memorias de un sueño hace referencia a un pasado familiar en el que la desaparición forzada es la protagonista en las voces de la madre, los hijos y el padre desaparecido. El padre desde un lugar íntimo como desaparecido y torturado durante diez días y diez noches, como dictaba el artículo 28 de la Constitución Política de Colombia de 1886, vigente en la década de los ochenta:

Esta disposición no impide que aún en tiempo de paz, pero habiendo graves motivos para temer perturbación del orden público, sean aprehendidas y retenidas, por orden del Gobierno y pleno dictamen de los Ministros, las personas contra quienes hayan graves indicios de que atentan contra la paz pública.

La madre desde el recuerdo del día de la desaparición y la búsqueda emprendida. Y los hijos desde sus evocaciones desdibujadas de la niñez. Asimismo, la apropiación de la historia de la vida familiar es asumida desde la exploración del espacio familiar como un espacio político, a partir de la subjetividad como el lugar de enunciación de esta propuesta.

Este camino permite abordar la hibridación de lenguajes en el espacio escénico contemporáneo, desde la creación de un espacio material que se centra en la desaparición, la invisibilidad y el silencio, materializados en una temporalidad suspendida, que proyecte la memoria autobiográfica. Lo anterior como consecuencia de haber revisado y profundizado en la tesis de la que se deriva este artículo sobre los nuevos espacios escenográficos desde el teatro naturalista, las tesis aristotélicas, la convención dramática, pasando por la crisis del teatro dramático, el romanticismo, la obra total de Wagner, etc., para llegar a los detonantes del cambio en las vanguardias artísticas, y, a partir de este espacio histórico recorrido, centrarse en la escena contemporánea con sus características y apuestas espaciales, temporales, incluso, ideológicas. También para reconocer las apuestas políticas que han enmarcado tanto el teatro como las artes visuales y que han conducido a introducir formas de provocación al espectador, a cuestionar la complacencia a la propia institución teatral, a destruir los valores del drama realista y a 
utilizar como herramienta ideológica y política el arte. En este punto, los desplazamientos tanto formales como conceptuales en las artes vivas y visuales, presentes desde finales del siglo XIX hasta nuestros días, permiten situarse en un momento contemporáneo de las relaciones entre lo político y lo poético, y en la puesta en crisis disciplinar, que ha llevado consigo el desplazamiento de una disciplina a otra.

Por otro lado, se asume el problema de la memoria y la autobiografía como una mirada de vuelta al sujeto, que es indudablemente un signo de esta época, pero con la pretensión de que adquiera otro sentido cuando se articule al problema de lo colectivo, para convertirse en hecho ético y político (Arfuch 2013, 13-14). Esta articulación se hace a través de la relación entre las artes visuales y las artes vivas, para encontrar en el espacio material y en la teatralidad posibilidades de articulación entre el yo y el nosotros, entre la narración y la dramaturgia, entre el relato y la imagen viva. Así, el concepto de invisibilidad y de desaparición son recursos estéticos y políticos para narrar-se y narrar-nos tramas de afecto familiar y social a partir de un hecho traumático que deja huella en el destino de los individuos e influye en la construcción de su subjetividad y de las relaciones intersubjetivas, incluso, a lo largo de varias generaciones.

Esta propuesta se centra, en consecuencia, en la casa como el lugar de protección y de construcción de afectos y tejidos absolutos, como recursos para hacerle frente al enemigo y a la muerte. Parte de la casa advirtiéndola como objeto y como lugar de apego y adhesión, "porque la casa es nuestro rincón del mundo", así como para indagar "Ios valores del espacio habitado" (Bachelard 2000,28) de algunos dispositivos escénicos a los que se reclama como referentes para este trabajo.

En definitiva, este artículo se presenta con una estructura de investigación en la que se indica la justificación y los aportes de este dispositivo escénico, en conjunto con algunos elementos conceptuales y del contexto, que se desprenden de las hipótesis y los objetivos de esta propuesta. Sin embargo, el interés especial se centra en la metodología de creación artística, que inicia en solitario y se consolida en su fase de producción, en colectivo.

\section{Justificación}

Preguntas metodológicas sobre ¿cómo narrar una experiencia anclada en un particular momento histórico para que pueda ser comprendida desde el presente? repercuten en nuestra memoria tanto individual como colectiva, y tratamos de responder esperanzados, porque estamos en el momento histórico preciso, después del último proceso de paz firmado con una de las guerrillas más antiguas de Colombia: las Fuerzas Armadas Revolucionarias de Colombia (FARC) y la actual implementación de este acuerdo de paz.

Destacar este compromiso y el de otras guerrillas como el M-19 por lograr la consolidación de sus movimientos armados en grupos políticos pretende dar lugar a un desplazamiento en el discurso artístico e histórico y de su interpretación sobre este tema. Alcanzarlo implica establecer relaciones transdisciplinares entre las artes vivas y visuales para expandir los campos disciplinares con el intercambio de saberes y de lenguajes que potencien la presencia en el escenario como espacio de resistencia y de creación de comunidad. 
Evidenciar, además, que existen diferentes propuestas como el Centro Nacional de Memoria Histórica (CNMH) que recoge un amplio archivo virtual con informes sobre la desaparición forzada en Colombia y publicaciones como ¡Basta ya! Colombia: memorias de guerra y dignidad, son incentivos para pensar que históricamente es el momento idóneo para volver al recuerdo. Sin embargo, también hay un discurso que, incluso, niega este conflicto y que nubla estas propuestas, que revictimiza a las víctimas y que invisibiliza los testimonios que no se ajustan a dicho discurso; además, de ser escasos los relatos artísticos e históricos de memoria, asumidos desde los hijos sobre sus padres revolucionarios y activistas de grupos guerrilleros que no pudieron hacer el paso a la vida civil sin antes sufrir la desaparición y la tortura.

En esta dirección, desde el trabajo subjetivo de la memoria, nos preguntamos ¿cuál o cuáles son los objetos detonantes de nuestro recuerdo y cuál el lugar o imagen que sirve de hilo conductor en la narración? El lugar es la casa como arquetipo del cobijo y la familia que la habita. Los objetos son muebles, juguetes, hilos, ventanas y puertas en una explosión suspendida que representan la temporalidad detenida en un espacio onírico. Esta explosión (figura 6) representa no solo la emoción que siente la autora, sino también la situación traumática en sí y el momento que divide el antes y el después de la detención de su padre; es, sin duda, la justificación formal y conceptual sobre la violencia proyectada en el espacio.

\section{Objetivos}

El objetivo general de este trabajo es crear y producir una acción poético-política que trabaja con la noción de desaparición forzada en el conflicto armado colombiano en una puesta en escena con características de instalación performativa en la ciudad de Valencia (España).

\section{Objetivos específicos}

- Dar lugar a un desplazamiento en el discurso histórico-artístico sobre la desaparición/ detención dentro del conflicto armado en Colombia.

- Activar la memoria desde un territorio flexible y subjetivo, entre el discurso y el trauma, entre el documental y la ficción, a través del discurso autobiográfico.

- Experimentar las posibilidades desde el diseño de la imagen audiovisual, el sonido, el cuerpo y el espacio, alternativas narrativas y dramatúrgicas coherentes, en la producción artística Memorias de un sueño. 


\section{Hipótesis}

La hipótesis principal es demostrar que la investigación y creación artística, enfocadas en el retorno a la memoria desde una perspectiva crítica, contribuye a las acciones poético-políticas actuales, sobre la noción de desaparición forzada en el posconflicto armado colombiano.

De esta hipótesis, se desprenden cuatro tesis más que responden a los objetivos específicos de este proyecto artístico. En primer lugar, dar espacio a un desplazamiento en el discurso histórico-artístico dominante permite otras interpretaciones y lecturas sobre la desaparición forzada y el conflicto armado en Colombia. En segundo lugar, demostrar que la práctica artística es un proceso dinámico y reconocer la expansión de los campos disciplinares y la puesta en crisis disciplinar que esto supone. En tercer lugar, reconocer el contexto político que propició esta práctica artística como una acción poético-política en contraposición con lo enmarañado de la memoria individual para explorar su carácter ambiguo. En cuarto lugar, registrar la expansión de los campos disciplinares tanto de las artes visuales y el diseño como del teatro y la danza, para plantear críticamente esta puesta en "crisis" disciplinar.

\section{Contexto y conceptos}

En este apartado, se abordan dos caminos: uno, el del contexto social y político de la década de los ochenta en Colombia, en particular, la práctica de detención/desaparición forzada, la cual propicia esta práctica artística; dos, el de los elementos conceptuales sobre el espacio material escénico, la memoria y la autobiografía, como nociones que la sostienen y la impulsan.

Comenzamos entendiendo la desaparición forzada de personas como la extracción de un sujeto de derecho para ser sumergido en un estado de incertidumbre (Salvi 2018), que inició en Colombia a finales de la década de los setenta, pero que no fue tipificada como tal hasta el año 2000, lo que significa la falta de cifras sobre las víctimas de este delito, ya que solo comenzó a penalizarse y a contabilizarse de forma sistemática hasta el año en que fue tipificada, lo que "implica que muchas desapariciones ocurridas antes puedan haberse catalogado como otros delitos" (Sánchez 2014, 17).

En esta dirección, y a pesar que en 2007, a partir de la Convención Internacional para la protección de todas las personas contra las desapariciones forzadas, el concepto adopta una forma más precisa en la que se incluyen factores determinantes como el ejecutor (fuerzas estatales o paraestatales) y la víctima (individuo o ciudadano) (Gatti 2018, 8); en Colombia, resulta difícil identificar y aplicar estas nuevas concepciones debido a que los actores del conflicto son diversos y las formas de operar difusas, contrario a lo que ha pasado en dictaduras como las de Argentina, Chile y España.

El "pasado que no pasa", utilizado para referirse a la presencia de pasados traumáticos y a la persistencia en el presente de un recuerdo conflictivo y los efectos de este sobre el futuro (Salvi 2018, 23), refleja la necesidad y oportunidad de acabar con el pacto de silencio y vincular a la familia y a la colectividad con esa experiencia del yo que se sitúa inevitablemente en un contexto social más amplio y repetido por toda América Latina, como es desaparecer. 
En este contexto, muchos padres y madres que lucharon en estas circunstancias, que tuvieron un sueño por una vida mejor y más justa para sus hijos, han desaparecido o han reconstruido sus vidas (después de ser desaparecidos y torturados), algunos en el exilio, otros en Colombia. Estos padres y madres hicieron posibles cambios importantes en derechos sociales y ciudadanos al llegar a la Asamblea Nacional Constituyente de 1991 para la promulgación de una nueva carta política en Colombia (Grabe 2010, 26), como fue el caso de los miembros del M-19.

Ahora bien, sobre el M-19 se han escrito distintos textos históricos y críticos, entre ellos, los aportes de Grabe (2010), en cuyos artículos la autora plantea una revisión histórica del origen de esta guerrilla con sus motivaciones internas y externas, que fueron determinantes en su formación. Además de analizar y defender el camino hacia la paz a partir de una reconciliación política cuestionando las doctrinas revolucionarias para plantear las armas como un instrumento y no como un principio. Estas iniciativas que intentaban romper el círculo de la violencia en Colombia, por lo menos en manos de esta guerrilla, no han sido suficientes debido a que en Colombia es todavía difícil de aceptar la idea de un pacto social y político fruto de una negociación y no de un vencedor y un vencido, en que es difícil el reconocimiento compartido de la crisis (22).

En consecuencia, las víctimas y los victimarios se confunden en el conflicto armado que ha vivido Colombia desde estos años, debido a que no solo las guerrillas han sido las causantes de las víctimas, sino también el Estado, los paramilitares y el narcotráfico. Así que hay relatos que no se han contado desde los activistas de grupos armados como el M-19, la Unión Patriótica (UP) y otras guerrillas que firmaron procesos de paz frustrados gracias al exterminio, la desaparición y la tortura de sus miembros durante esos procesos.

Pasando al segundo punto sobre los aspectos conceptuales, nociones como memoria y autobiografía son abordadas a partir de un corpus heterogéneo de voces por Arfuch (2003), lo que ha permitido evidenciar claves interpretativas de lo que la autora denomina "subjetividad situada". En este plano de sentido, el tiempo es entendido como una entidad social "configurada a través de los ritmos colectivos de relación humana con el mundo" (Wajcman 2017, 16) y la memoria como la capacidad de recordar acontecimientos políticos, sociales y culturales que tuvieron un carácter "especial" en un tiempo y en un espacio determinados para asumir una búsqueda de sentido a ese acontecimiento.

En esta búsqueda de sentido, el espacio material e inmaterial de las artes vivas permite a las artes visuales otro tipo de comunicación que se da en el momento de la presencia, y es en este punto donde la revisión del trabajo de Sánchez (2014) ha permitido visualizar la historia de las relaciones entre las artes visuales y vivas, comprobando que entre la ficción y la realidad, lo privado y lo púbico, lo poético y lo político existen cruces propios de la escena contemporánea que se intentan rescatar en esta propuesta a través de la poetización de la violencia.

Esta visualización considera que desde el inicio del siglo XX la escena actúa como un laboratorio natural de experimentación de artistas de diferentes disciplinas que convierte el espacio escénico en una simultaneidad de signos donde se pueden seguir relatos paralelos y sustituir un signo por otro; la luz, el sonido, el movimiento y la imagen conforman el espacio como un nuevo agente dramático (De Blas 2006, 13) y no solo como un agente narrativo que da información al espectador y a los actores (cuerpos) en escena. En consecuencia, se revisan los aportes a estas transformaciones que fueron posibles gracias a teóricos como Adolphe Apia, Edward Gordom Craig y Josef Svoboda, que desde distintos lugares apoyaron la mutación del espacio escénico como un espacio de experimentación y de unión de las artes.

En esta dirección, el trabajo de Breyer (2005) sigue vigente por su visión sobre el hecho teatral desde la perspectiva del diseño de la escena como apuesta metodológica y de este mismo como resultado de una tarea integradora y, por qué no, interdisciplinar. Además de centrarse en la superación de la dependencia del teatro respecto del texto dramático literario, prestando atención al enfoque visual, objetual y corporal, nociones de las que partimos en esta investigación. 


\section{La metodología}

\section{Área de estudio}

Esta investigación artística está pensada en la intersección de tres elementos: el análisis documental, el espacio escénico contemporáneo con sus prácticas poético-políticas susceptibles de ser analizadas y la relación entre la teoría y la práctica artística propia como lugares de experimentación. Empieza en Colombia y termina en España durante el proceso de doctorado de la autora y como parte de ese estudio.

La creación de este dispositivo se hace a partir de la revisión de documentos personales (cartas, testimonios orales, fotografías) y documentos institucionales (periódicos, testimonios históricos). La narración de los hechos y recuerdos tanto sociales e históricos como íntimos y afectivos se hacen a través de una historia de vida como recurso metodológico etnográfico que se desprende de la entrevista narrativa sobre una experiencia vivida.

\section{Referentes artísticos}

Sobre esta aproximación a la práctica artística, el trabajo de los últimos años del laboratorio Mapa Teatro de Bogotá ha sido esencial, porque "ha hecho énfasis en la producción de acontecimientos poético-políticos mediante la construcción de etno-ficciones y la creación efímera de comunidades experimentales" (Mapa Teatro 2020), lo que se traduce en la tensión entre la realidad etnográfica y la ficción de la imagen cinematográfica. El trabajo de Mapa Teatro ${ }^{1}$ es importante, además, por la hibridación de lenguajes utilizados en sus apuestas creativas, lenguajes artísticos que se conjugan en organismos vivos, lenguajes como el teatro, la ópera, la radiofonía, las instalaciones para imagen y sonido, las intervenciones urbanas, las acciones y conferencias performáticas.

En esta línea creativa, si abordamos este objeto de estudio como hecho social y como acto subjetivo, estaríamos entre el proceso y el contexto; tal y como se platea en el catálogo con motivo de la exposición William Kentridge: basta y sobra, organizada por el Museo Reina Sofía entre 2017 y 2018, lo político es el "fondo" de la obra de Kentridge, donde el lenguaje es la forma y su despliegue el fondo, lo político como algo intermitente, discontinuo y contradictorio (Méndez de Vigo 2017, 5).

Al igual que hace Kentridge en algunas de sus producciones, se propone un solo personaje que encarne varias voces en una sola voz, que diga lo que dice mi padre, mi madre, mi hermano, con una voz formada por la multiplicidad de voces de la familia y del contexto. Retomando, además, los elementos en los que coinciden Mapa Teatro y Kentridge: la mezcla de géneros, la hibridación de lenguajes, la ausencia de jerarquías, la polifonía de los medios, las relaciones inesperadas e influencias heterogéneas, y la ausencia de una lectura única por parte del espectador.

Por su parte, la compañía teatral valenciana A Tiro Hecho ${ }^{2}$ es un referente importante debido a las relaciones que establece entre las artes visuales y vivas, el manejo del cuerpo vivo y el vestuario cotidiano que utilizan en sus puestas en escena. El trabajo horizontal y no jerarquizado ni en la dirección de la obra ni en la utilización de diferentes lenguajes artísticos son sin duda elementos del proceso creativo que se rescatan, además de su compromiso político a través de un lenguaje poético. 
Otro referente importante es la compañía Sr. Serrano de Barcelona, que, con el uso de multipantallas y diferentes leguajes tecnológicos en escena, propician reflexiones sobre la relación entre la tecnología y el espacio; además, el uso de metáforas para la construcción conceptual de sus propuestas es lo que retomamos de esta compañía teatral contemporánea.

Escenógrafas como Cris Blanco que en el proyecto The Neverstarting Story ${ }^{3}$ (2008) trabaja el espacio doméstico construido en directo incluye al espectador en la construcción de la escena y el espacio. En esta dirección, Anna Viebrock ${ }^{4}$ en House of Usher presenta espacios domésticos divididos en lugares fragmentados en escena donde pasan a la vez diferentes cosas, distintas acciones se despliegan frente al espectador en distintos espacios contiguos.

Asimismo, artistas como Damián Ortega en su obra Cosmogonía doméstica ${ }^{5}$ (2014) muestran el movimiento continuo y la coreografía cambiante entre los objetos cotidianos y el público a través de la suspensión de objetos en el espacio y en el tiempo, con lo que logra la visión de un todo a través de la fragmentación de sus partes.

Doris Salcedo, por su parte, trata en sus obras la violencia como experiencia cotidiana, como se puede ver en la serie La casa viuda6 (1992-1996), que parte de una mirada testimonial, para buscar el horror tanto en los objetos como en los lugares que han sido marcados por la violencia en Colombia.

Azkona\&Toloza ${ }^{7}$ es otra agrupación que ha trabajado proyectos escénicos documentales, de los que abordamos su puesta en escena Tierras del Sud SA (2018), que es la segunda parte de la trilogía escénica Pacífico. Esta propuesta es una coreografía documental sobre el neocoIonialismo y construye el espacio del paisaje en directo con elementos efímeros, ligeros y de materiales económicos, diseñados para ser transportados fácilmente y para que expongan esquemáticamente la arquitectura del paisaje. Además de darles voz a otras personas, como en el caso de esta propuesta, en la que la autora, que no es actriz, hace presencia en escena, trabajan sobre un conflicto vivo y actual, demostrando que, así los proyectos evolucionen en el tiempo, al igual que los lenguajes artísticos y tecnológicos empleados, las dinámicas del mundo no cambian.

Estos y otros referentes han sido separados por categorías en torno al lenguaje artístico empleado: documentales, instalaciones y montajes escénicos, para luego coexistir agrupados por su relación con hechos políticos y el lenguaje poético empleado, lo cual ha servido para hacer la estructura de la obra y relacionar la dramaturgia con el espacio escénico.

\section{Fases del proceso creativo}

\section{Fase de documentación}

En esta fase, se clasifican y seleccionan frases encontradas en documentos institucionales y personales como entrevistas y noticias, audios y videos documentales de la década de los ochenta que tengan que ver con el M-19, violencia de agentes del Estado, persecuciones, manifestaciones, toma y retoma del Palacio de Justicia, para crear relatos visuales y textuales que sirven de guía a la intérprete de la lectura dramática. 
En esta dirección, se trabaja la noción de memoria histórica desde la reconstrucción del pasado contiguo con las perspectivas del futuro. Además de hacer una evaluación del impacto de la guerra en el seno familiar, a través de entrevistas narrativas, retratos, relatos y acciones performativas retratadas a partir de fotografías (figuras 1-2). Asimismo, se determina el concepto gráfico y la dramaturgia de la obra desde una perspectiva del espacio visual y sonoro antes que el textual (figuras 3-7) a través de la creación de un guion diagramático (figuras 11-12).

\section{Fase de experimentación}

En esta fase se editan videos y fotografías, y se mezclan con discursos complementarios de diferentes actores del conflicto. Se hacen montajes audiovisuales experimentales con partes de entrevistas, animación 2D, fotografías documentales y del álbum familiar (figuras 4-7). Además, se graban y editan sonidos de instrumentos, de voces y de relatos que activen las acciones dentro de la obra instalativa.

En la construcción del espacio, se crean varios objetos casa con pantallas para hacer microproyecciones y paneles bordados para proyectar que sirven como multipantallas (figuras 8-10).

El diseño de los soportes gráficos y audiovisuales de divulgación hacen parte del proceso de experimentación tanto inicial como final, ya que se adaptan y crecen junto con el resto de la propuesta artística (figuras 13-14).

\section{Fase de producción}

En esta fase, se hace el inventario de los materiales que deben ser reciclados y de los materiales constructivos como cuerdas, tensores, muebles, pintura y soportes. Además, se hacen pruebas de vestuario y montajes digitales como elementos ilustrativos para ese proceso de producción, se componen los planos de montaje y se genera un presupuesto a partir de los planos del espacio del teatro.

En esta fase, se lleva a cabo el montaje de la escenografía y se hacen los ensayos correspondientes de las acciones en el espacio escénico, es decir, se perfilan las relaciones entre cuerpo, objetos escenográficos, luces y sonido. 
Desarrollo

\section{Fase documental}

En esta primera etapa del proceso creativo, se rescatan ideas de la entrevista hecha a un exactivista del M-19, realizada por el comunicador social de la Universidad del Valle (Colombia) Carlos Clavijo bajo las directrices de la autora en agosto de 2019. Además, se llevan a cabo otras entrevistas narrativas a la autora de este proyecto, su madre y su hermano en septiembre del mismo año, para contrarrestar y poner a dialogar los recuerdos familiares entre sí. Igualmente, se retoman frases de declaraciones hechas por miembros del M-198 como Jaime Bateman Cayón, Carlos Pizarro Leongómez, Álvaro Fayad, Antonio Navarro Wolff y Vera Grabe Loewenherz, en diferentes momentos de su incursión política y durante el proceso de paz con el Gobierno Nacional.

Se proponen tres momentos para la construcción de un guion diagramático, que parte de reconocer el presente del pasado y del futuro. Estos tres momentos se dividen en:

- El contexto, el antes, el sueño, que hace referencia a la década de los ochenta en Colombia cuando había "una fuerte tendencia a buscar organizaciones que pudieran permitir a los jóvenes organizarse en la lucha social del país (Carlos Cuéllar, comunicación personal, 24 de agosto de 2019). Además de enmarcar el surgimiento del M-19 a finales de esta década y el papel de los jóvenes y de los grupos barriales que se van fortaleciendo con este movimiento de corte nacionalista.

- La detención, el evento, la pesadilla, que pone en retrospectiva la incursión del F2 en nuestra casa en Popayán (1982), donde el comandante de la policía de la estación del municipio de Silvia, en el departamento del Cauca, toca a nuestra puerta, mientras cientos de uniformados con cascos grises ocupan todas las partes posibles por fuera de la casa. Esa madrugada se llevan a mi padre y otros amigos suyos que estaban esa noche en nuestra casa. Los suben a un camión, los ponen boca abajo con los ojos vendados y les dicen que los Ilevan para el basurero de Popayán, que los van a matar.

- La vida, el después, la memoria, pone sobre la mesa el papel de presentar la memoria desde un territorio enmarañado, flexible y moldeable entre la ficción de un sueño y el documental de un suceso, para reconocer el carácter ambiguo de la visión sobre el futuro a través de la evaluación del impacto de este acontecimiento sobre la familia.

Estos tres momentos finalmente no quedan de esta forma, sino que el tercero pasa a ser primero para empezar desde el presente haciendo una revisión del pasado y presentando el presente como un pasado y a la vez como un futuro, ambos destruidos, ambos suspendidos, en una explosión que ha detonado dentro de la casa y que ha dejado interrumpido el tiempo y el espacio por un instante. En este presente, está la familia de la autora, no sus padres, sino sus hijos y su marido, que también han tenido que pasar por un momento de detenimiento debido al estado de alarma de la covid-19 y han tenido que habitar la casa de otras maneras y bajo otras dinámicas. 


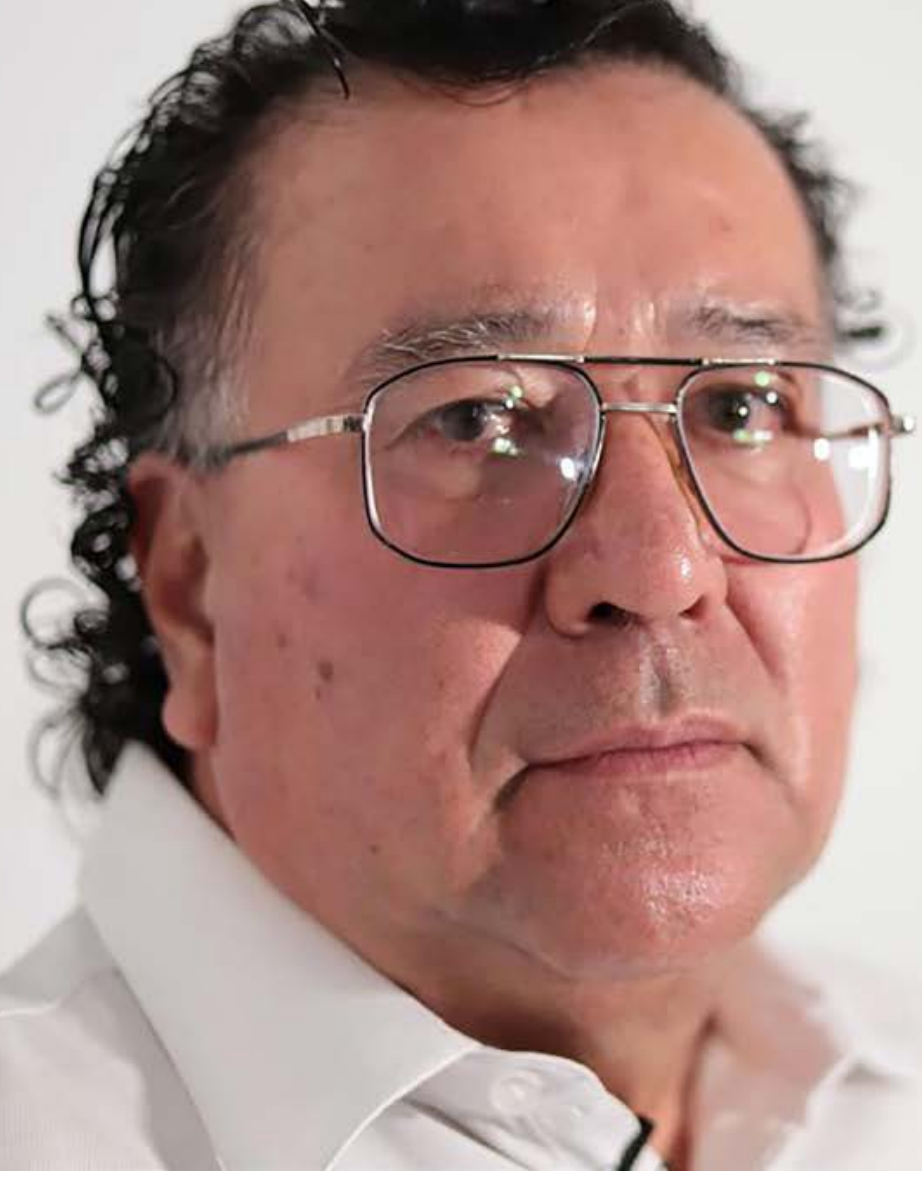

\section{Entre las entrevistas, los retratos y la performance}

En esta fase, después de hacer las entrevistas al protagonista de la historia y su familia, se

hacen retratos de estos entre septiembre de 2019 y febrero de 2020, con la inclusión de acciones para ser proyectadas en la obra y para ser intervenidas gráficamente (figura 2).

Estas acciones performativas permitieron al protagonista y a su hija reconocer el fantasma del enemigo, noción imperante en la realidad colombiana. Además de probar a ponerse la máscara del enemigo y de la víctima al mismo tiempo para actuar su historia (espacialmente la tortura) de forma no literal sino simbólica.

\section{Entre la estructura narrativa y la dramaturgia}

\section{Parte 1: Sueños cruzados}

Los objetos (muebles rotos por una explosión) están dispuestos más allá del escenario y se dispersan tanto por el techo como por el suelo hasta el lugar del espectador.

Hay una niña en escena tocando un piano de juguete que desaparece cuando la intérprete entra en la sala destruida.

Las luces del teatro son tenues inicialmente, van iluminando el recorrido que hace la intérprete, quien, en un monólogo sobre una experiencia vivida cuando era niña y que ahora recuerda como un hecho personal e histórico, muestra diferentes voces de la memoria y el conflicto. 


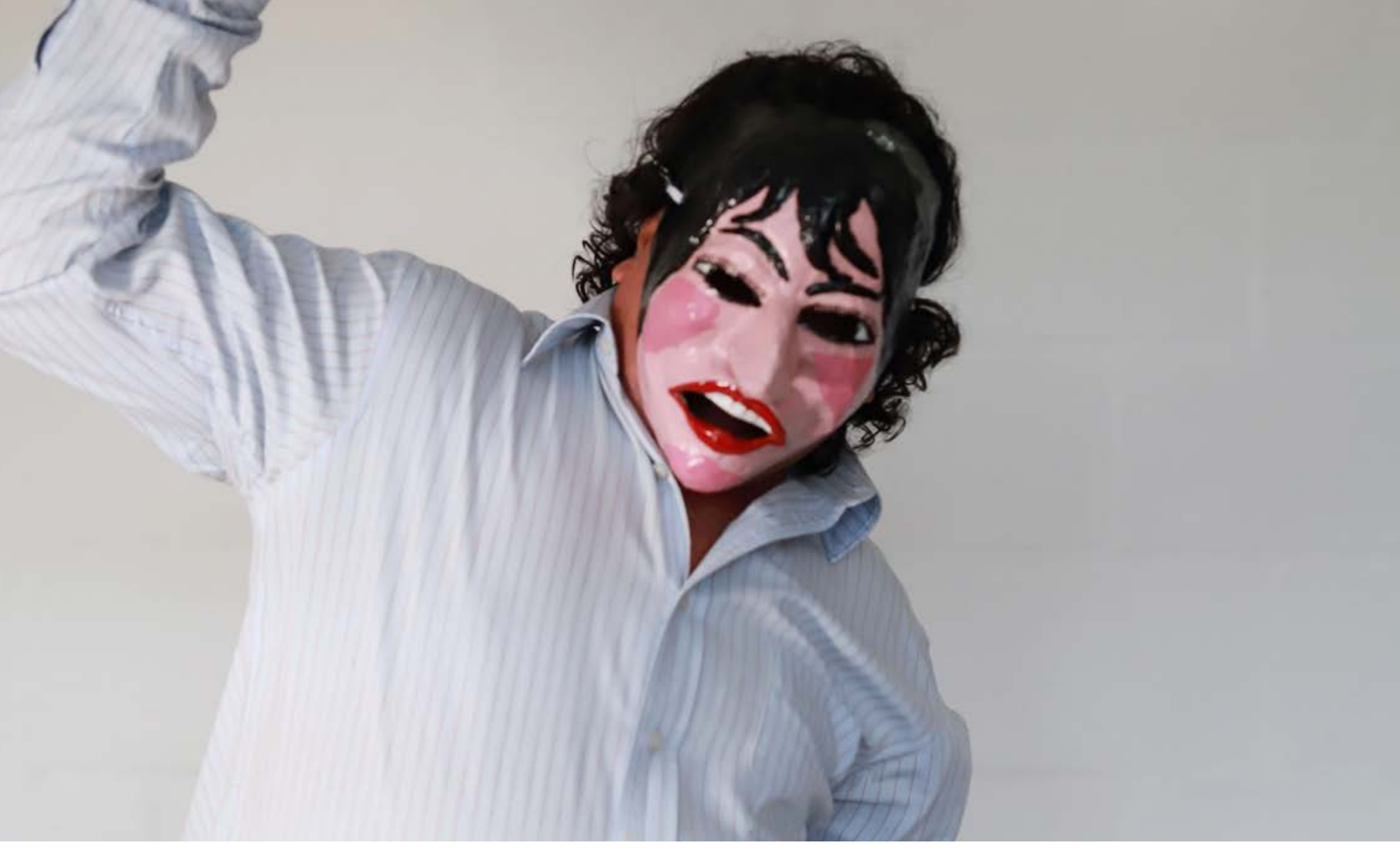

Figura 2. Carlos Clavijo, Retratos y performance, 2019, fotografía. Fuente: Elaboración propia.
Los cuerpos que habitan el espacio deambulan por la casa como perdidos, son sombras y cuerpos proyectados sobre las paredes. La intérprete reconstruye parte de la casa, levanta muebles caídos y ubica los dispositivos tecnológicos que darán vida y paso al sonido y a la imagen sobre el espacio.

Al inicio aparecen imágenes de la actualidad familiar y social, como el piso que habitan en Valencia sus hijos y marido durante el confinamiento por el estado de alarma, junto con imágenes de personas que no pueden tocarse, sino mantener distanciadas para evitar el contagio.

Al final, la intérprete dice algo que no debía, algo pequeño que activa una acción de persecución, para contextualizar el momento histórico y actualizarlo.

\section{Parte 2: Pacto de silencio}

Como es necesario mostrar la experiencia de sometimiento, de desconexión del mundo que padecen los que han sido desaparecidos, perseguidos y torturados, la intérprete se queda detrás de un panel y parece una sombra, se sienta, se esconde, se arrodilla y se acuesta boca abajo, mientras se proyectan animaciones de hombres con cara de perro y de personas que caminan y desaparecen sobre las paredes de la casa.

Se percibe el conflicto entre hacer y no hacer, la experiencia que sufre alguien que es torturado, la desconexión entre su cuerpo y su mente. El espectador se convierte en otro habitante de esta casa, sigue a la mujer, sus acciones, su persecución y su búsqueda. 


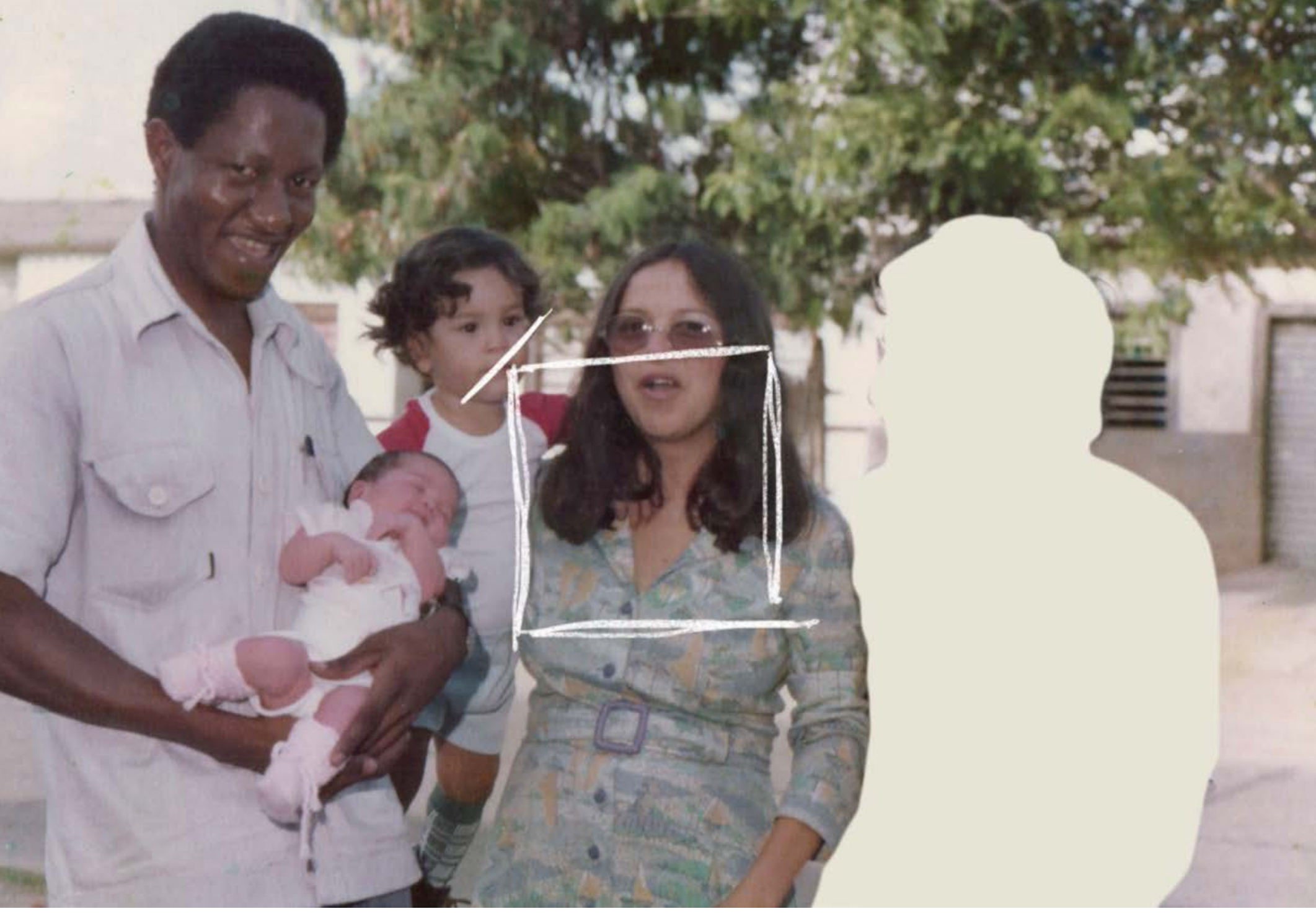

Otras imágenes que conforman el recuerdo son las del álbum familiar, imágenes que son recogidas e intervenidas para representar tanto la actualidad como el recuerdo y el vacío de una persona que ha sido desaparecida y borrada de las fotografías (figura 4).

Los sonidos de instrumentos como la trompeta, el bajo y un piano de juguete hacen referencia a esa creación artística que es lo único que nos queda para superar nuestros miedos y rabias. Los cantos de nanas por familiares de la autora, relatos grabados por el padre, la madre y la autora, serán distorsionados y puestos en escena en conjunto con los demás elementos visuales. Sonidos de la naturaleza, sonidos de la radio, noticias de la década de los ochenta de la radio y la televisión, sonidos de botas de soldados, gritos, pisadas, murmullos, el silencio y el ruido de una explosión son sonidos que hacen parte de la realidad documentada en una Colombia que no cambia.

Ahora bien, dado que el concepto espacial se centra en la temporalidad suspendida de una explosión como justificación conceptual del trauma y la violencia proyectadas en el espacio, el concepto formal se construye con muebles con un diseño atemporal, con líneas rectas y en colores naturales como el de la madera. Algunos muebles son intervenidos con pintura y partidos en varias partes. Ventanas con cristales rotos y partes de mesas pegadas en la pared. Escombros en el suelo y cables, y computadores que se van a usar en escena.

El material reciclado de los muebles es el concepto material debido a que se requiere viajar con la pieza y no es posible por la magnitud de los objetos, así que se deben reciclar en la ciudad donde se vaya a hacer el montaje y según el lugar donde vaya a ser montado. Así, en Valencia (España), el material es recogido en casas y botaderos, y el lugar de instalación es el Teatro Círculo ubicado en el barrio Benimaclet. 

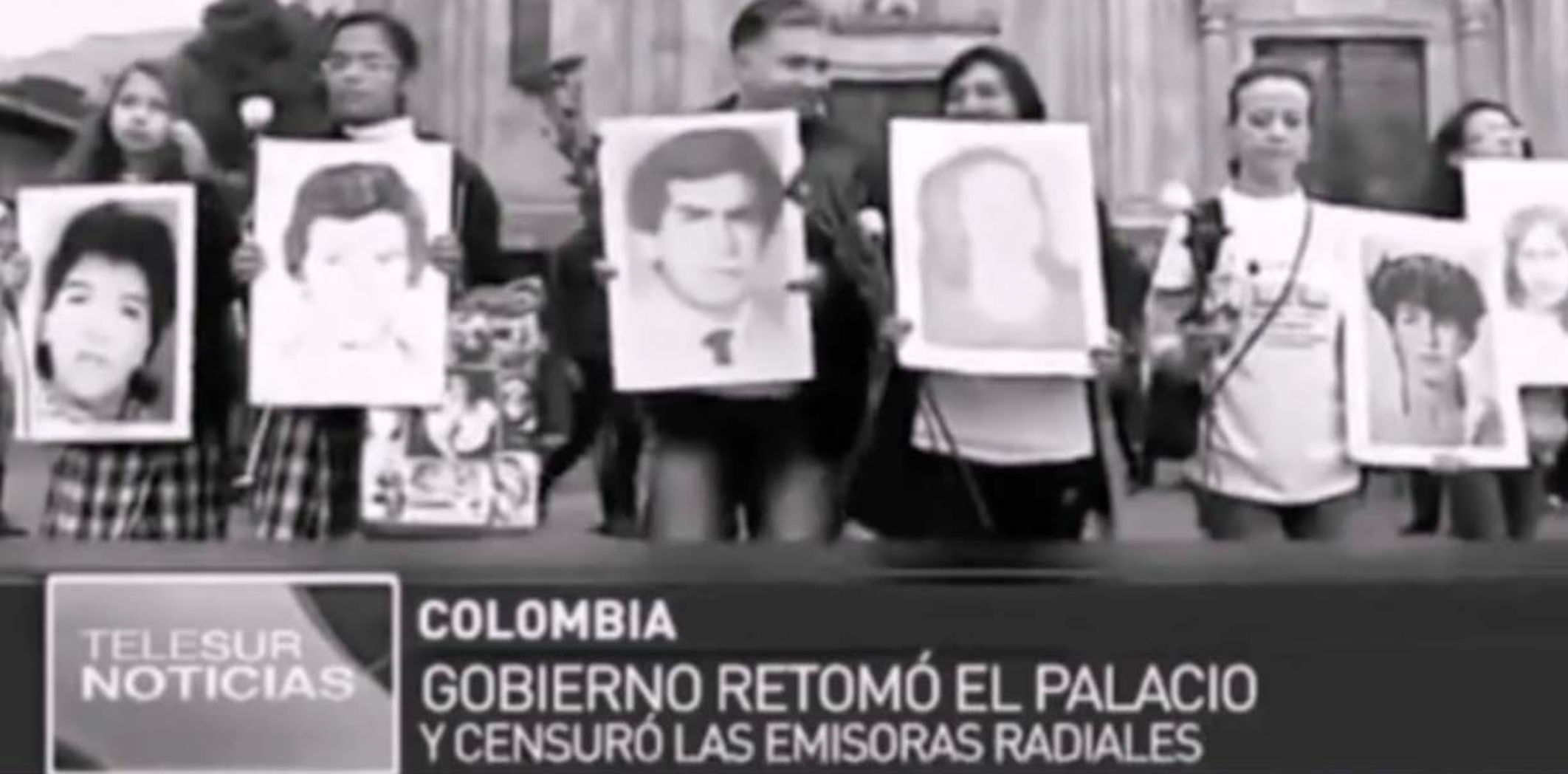

Las imágenes documentales son buscadas en archivos virtuales de bibliotecas, en archivos de televisión y radio, y en el $\mathrm{CNMH}$, además de en canales de YouTube, ${ }^{9}$ donde hay un amplio material sobre el grupo guerrillero, la toma del Palacio de Justicia y manifestaciones de estudiantes. Estas imágenes son intervenidas para que hagan parte de una visión más ambigua de la historia para lograr otras interpretaciones posibles (figura 5).

En esta misma línea, las imágenes producidas desde videos de la hija y del padre de la autora como acciones performativas son transformadas en relatos visuales y animaciones, que recrean, entre otras, la posibilidad de ser uno y otro personaje al mismo tiempo, de ser víctima y victimario (figura 6).

En esta última fase de la experimentación con la imagen, se toman los retratos hechos por el comunicador social Carlos Clavijo, para ser intervenidos por la autora y crear composiciones para proyección continua de unos cuatro canales que se mezclen en un solo plano, con un único personaje como símbolo del rompimiento del pacto de silencio consigo mismo (figura 7).

Entre la manipulación de la imagen para crear otros retratos, otros rostros y otros mensajes, aparece la experimentación con materiales como el hilo, el cual se vuelve protagonista a través del bordado y de una idea sobre las cadenas infinitas de afectos que hay que crear para lograr los sueños y para hacernos invisibles a la muerte. El hilo se usa para bordar cuatro paneles de dos metros de alto: primero, se hacen impresiones en linóleo sobre la tela y, luego, se bordan con diferentes colores, como dibujando sobre ella. Estos paneles son a su vez representaciones del paisaje que están dentro de la casa y representaciones de ventanas y puertas de armarios derruidos (figura 8).

Finalmente, las maquetas efímeras con forma de casa que protegen y a la vez se abren para otros acontecimientos son representaciones arquetípicas de un espacio habitado que nos acompaña a través de nuestras vidas y que, por lo general, asociamos al cobijo y al resguardo de nuestros padres. Sin embargo, este lugar también puede ser violentado desde dentro del mismo seno familiar o desde fuera por agentes que producen ciertas anomalías a partir de violentar las relaciones ahí presentes, como la detención/desaparición violenta de uno de los sujetos que la habitan (figura 9). 


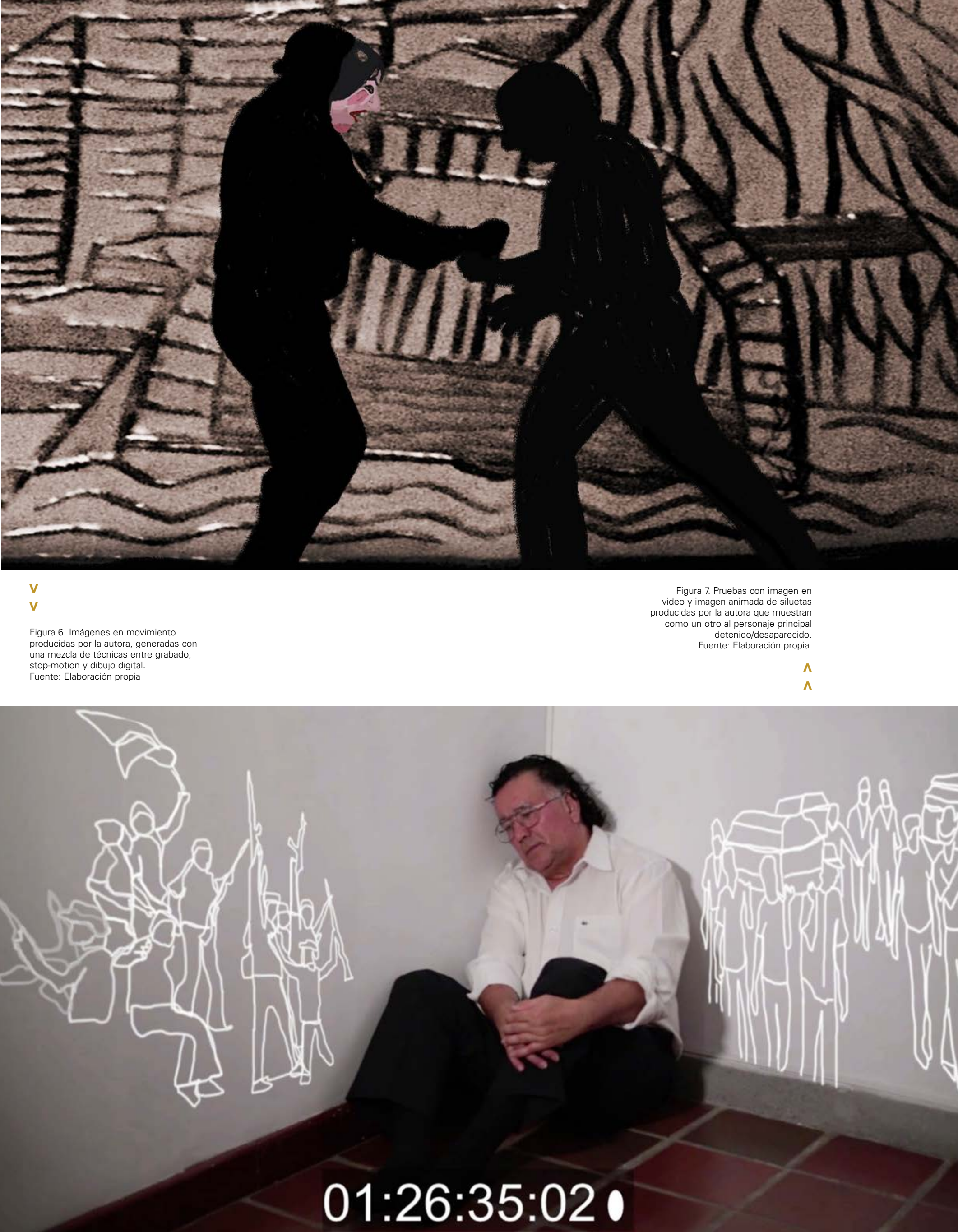




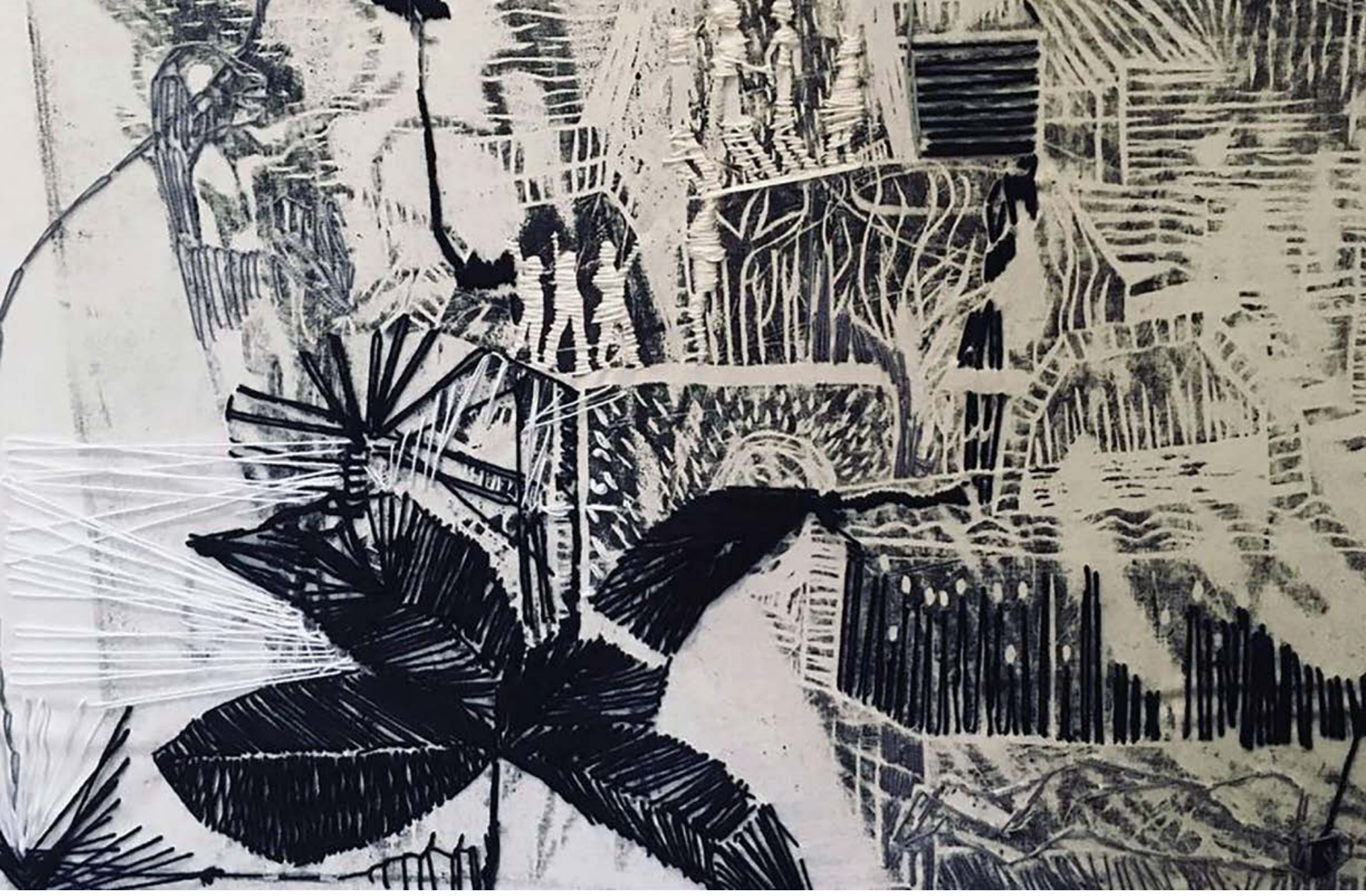

Fase de producción

Este proceso que empezó en solitario y que luego se abrió espacio para la co-creación familiar se vuelve colectivo al final en la etapa de producción escenográfica en la que un grupo de estu-

Figura 8. Experimentación con bordado y grabado sobre paneles de lino y madera creados por la diantes, pertenecientes a la asignatura de Práctica Escenográfica de la Universidad Politécnica de Valencia en el periodo académico 2019-2020, a cargo de Martina Botella Maestre, se unen al proyecto para realizar visualizaciones sobre los conceptos trabajados hasta el momento por la autora y se incluyen nuevas formas de producir el espacio como la idea del momento suspendido en el espacio, un momento en el que explotan los muebles dentro del área del teatro que representa la casa y que de alguna manera es la violencia que se proyecta en el espacio como una temporalidad suspendida, como una posibilidad que ofrece la manipulación de la imagen a través de la tecnología.

Durante esta última fase del proyecto, las estudiantes se dividieron en grupos de trabajo por experticia y motivación: el grupo de espacio, el de vestuario, el de imagen audiovisual y el de sonido, encargados de recolectar la información visual y sonora que hiciera falta y visualizar formas de composición por grupos según las imágenes y los textos ya producidos por la autora (figura 10).

Las maquetas en físico y en 3D han sido una evolución, un ir y venir entre lo análogo y lo digital, escudriñando entre la frialdad y limpieza del 3D y la riqueza visual de lo analógico, lo plástico de la propuesta que se evidencia en el manejo de las luces, del color, de los muebles y de la explosión en las maquetas físicas.

La materialización y el montaje de la obra se hacen en el Teatro Círculo de la ciudad de Valencia a puerta cerrada, debido al estado de alarma por la crisis sanitaria de la covid-19, que, en el momento de escribir este artículo, aún no ha concluido (figura 11). 


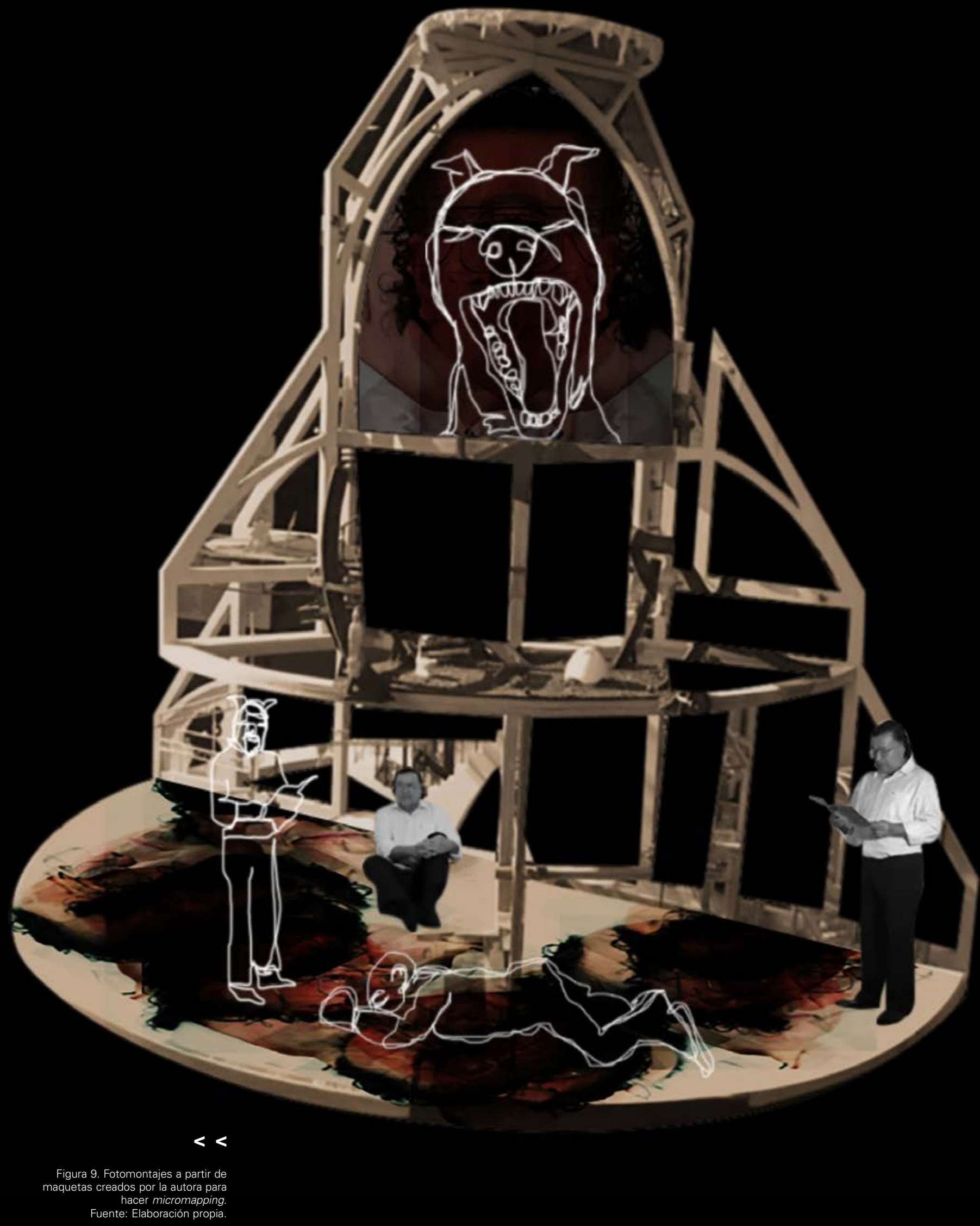




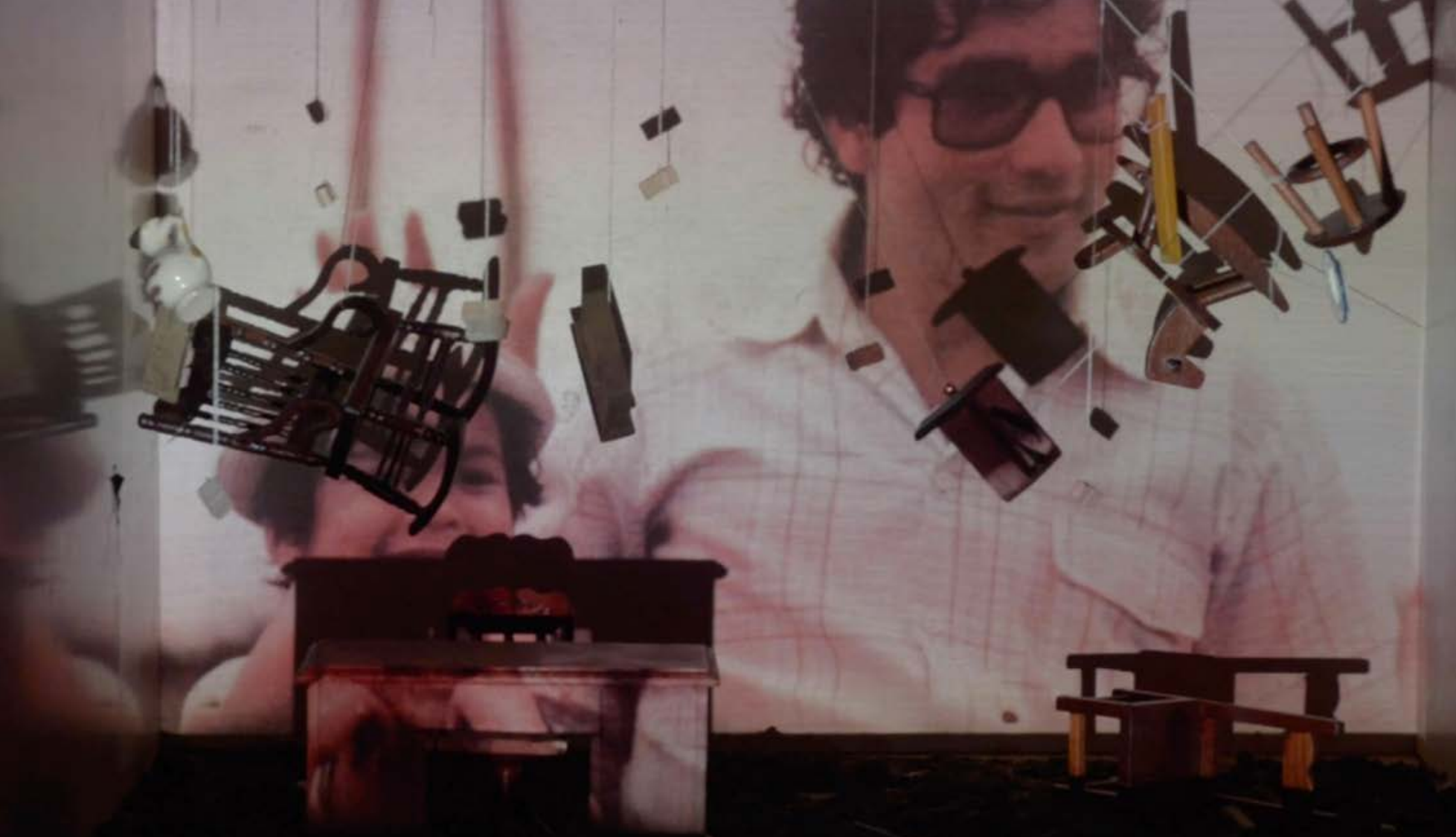

Figura 10. Maquetas en físico con micromapping realizadas en colectivo

entre la autora de este

proyecto y las estudiantes

María Mas, Marta Cazalla

y Daniela Muñoz.

Fuente: Elaboración propia.
Figura 11. Maquetas en 3D realizadas en colectivo por las estudiantes María Mas, María Roig y Daniela Muñoz.
Fuente: Elaboración propia.

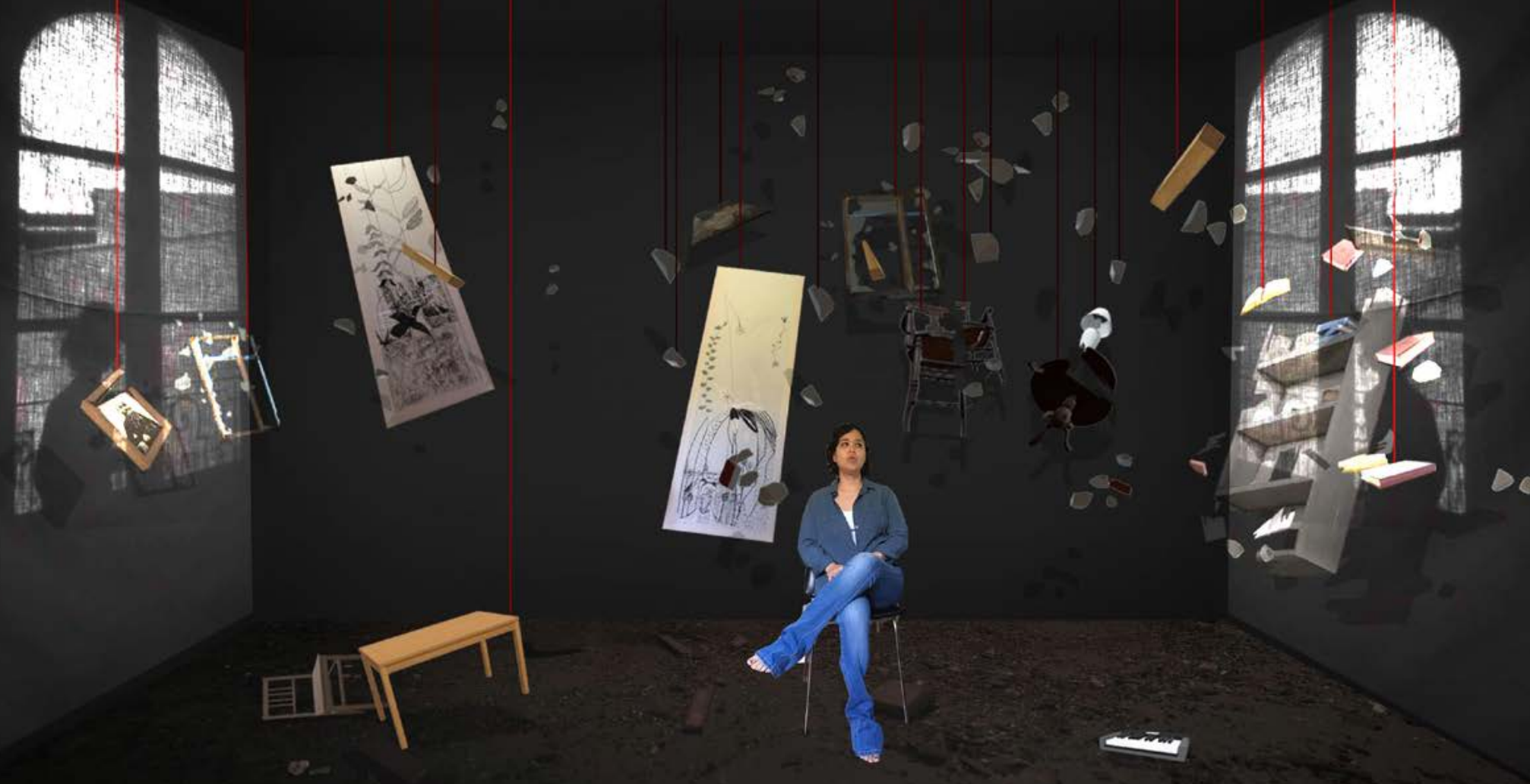




\section{Resultados}

\section{Sinopsis de la obra}

De niña tuve un ídolo, mi padre, se lo llevaron cuando yo tenía tres años de nuestra casa en Popayán, se lo llevaron los policías militares de la época y mi madre tuvo que gritarles para que no se la llevaran a ella también, gritarles que se la tenían que llevar con sus dos hijos, mi hermano y yo, así que finalmente la dejaron. No solo mi padre era mi ídolo, también lo era mi madre y Walter, su amigo; asimismo Cielo, su amiga, que está exiliada en México desde esa época, igual que otros amigos que se llevaron esa misma noche de nuestra casa. Ahora nosotros, los hijos de estos hombres y mujeres, exactivistas del M-19, apelamos a la memoria familiar para construir una imagen contemporánea del pasado. Esta imagen es concebida y presentada como una autoficción que presenta una autobiografía distorsionada, incompleta y dudosa, como mi propio recuerdo.

\section{Relato autobiográfico}

Recuerdo que vivíamos en una casa de dos pisos en Popayán y que una fría noche entraron muchos militares en ella con cascos grises que se veían hasta en el techo. Inundaban la casa como perros rabiosos, con sus botas pesadas y con sus manos tiraban todo al suelo. Abrían el famoso segundo cajón del armario y cogían el dinero que les habían pagado a mis padres que eran maestros en el departamento del Cauca. En este cajón, más tarde mi madre guardaría los regalos de Navidad y nosotros lo usaríamos de escalón para subirnos a la parte alta del armario y lanzarnos a la cama.

Recuerdo el pecho de Cielo que me sostenía, recuerdo sus grandes pechos calientes y cómodos ofreciéndome cobijo y seguridad en un momento caótico, de conflicto, de incertidumbre en el lugar que habitábamos y que reconocíamos antes de este hecho como un lugar seguro y cálido.

Recuerdo a mi padre "empequeñecido" embolando sus zapatos mientras esperaban en una tensa calma los militares. Mi padre limpiaba sus zapatos pacientemente, lo que creaba la tensión que siempre genera cuando hay una situación dramática, como cuando Walter murió años después: se metió a bañar horas y horas, y no quería salir para ir a verlo al hospital.

Recuerdo, igualmente, que vi a mi padre unos días después, no sé cuántos, pero serían unas dos semanas, en una celda; cuando mi tía Teresa y mi madre me llevaron a verlo, recuerdo el pasillo y sus grandes brazos abrazándome y ese gesto endurecido para no llorar.

Nunca había pensado en este episodio como una desaparición, porque volví a verlo, sino como el arrebato de un afecto, como la separación violenta de mi padre y como el sentimiento de humillación, miedo y rabia de mi madre.

Más tarde, en mi adolescencia, enfrenté a policías que pedían revisar mi bolso o que se nos acercaban en la calle, que nos paraban sin más; los enfrentaba, los cuestionaba, les gritaba, sin tener muy claro que lo que hacía era el reclamo por una deuda heredada. Yo no entendía mi rabia contra cualquier persona que llevara uniforme y que representara a las "fuerzas del orden". Siempre fue como un enfrentamiento entre dos jóvenes desde lugares distintos de poder, con 



\section{Dispositivo escénico}

La instalación está concebida desde un dispositivo tipo casa que ha sido destruido y fragmentado en diferentes partes de una misma habitación. La casa como arquetipo de la protección es transgredida con un hecho violento y convertida en otra cosa, en una explosión suspendida en el tiempo. Las acciones proyectadas tienen que ver con la invisibilidad de los sujetos, con tres generaciones caminando, subiendo y bajando escaleras y perdiéndose en medio de las paredes de la casa.

Esta instalación como una vía hacia lo "real" y como producto del despliegue de la memoria iría más allá de la representación y estaría entre lo real y lo imaginado, entre la historia y la ficción, entre la percepción y el espacio simbólico, entre lo visible y lo invisible, como lugares de resistencia.

\section{Escenografía}

La escenografía es una habitación de una casa destruida que se reconstruye en vivo, por lo que el ordenamiento en el espacio tiene que ver con la instalación in situ, es decir, en el espacio del teatro. Las paredes negras de este son usadas para proyectar el afuera, el lugar donde corren los soldados, donde pisan las botas, donde se oyen los perros ladrando. Dentro de esta sala, en el adentro, los muebles han explosionado hacia todas las direcciones de la habitación y solo queda entera una mesa y una silla que serán usadas por la intérprete; además de artefactos tecnológicos que serán dispuestos para su utilización en directo dentro de ese espacio.

La imagen audiovisual se caracteriza por la presentación y representación de elementos oníricos en relación con textos documentales, a través de conceptos como memoria, desaparición, transformación y reconstrucción.

\section{Concepto}

La dramaturgia está relacionada con la exploración del impacto personal y familiar en un caso de desaparición forzada desde una perspectiva de memoria. Haciendo uso de la metáfora de los perros como perpetradores, perros rabiosos que conviven con otra fuerza que habita la casa, así la casa será el lugar del antagonismo. No hay un plano de conjunto, sino que el espectador debe completarlo, debido a que la explosión de los objetos escenográficos instalados genera ambigüedad en el espacio y representa la violencia proyectada en una temporalidad suspendida. Asimismo, la ficción como el mecanismo que contribuye a pensar la violencia a través de dibujar una memoria viva, no como una fantasía que pretende oponerse a la realidad, sino a través de la construcción de acciones que activen el espacio material como instalación. La idea es, entonces, involucrar elementos anacrónicos en la puesta en escena, a través de una propuesta política tejida en términos estéticos no discursivos (Racière 2005, 13). 


\section{MUESTRA ACADÉMICA - TESIS DOCTORAL}
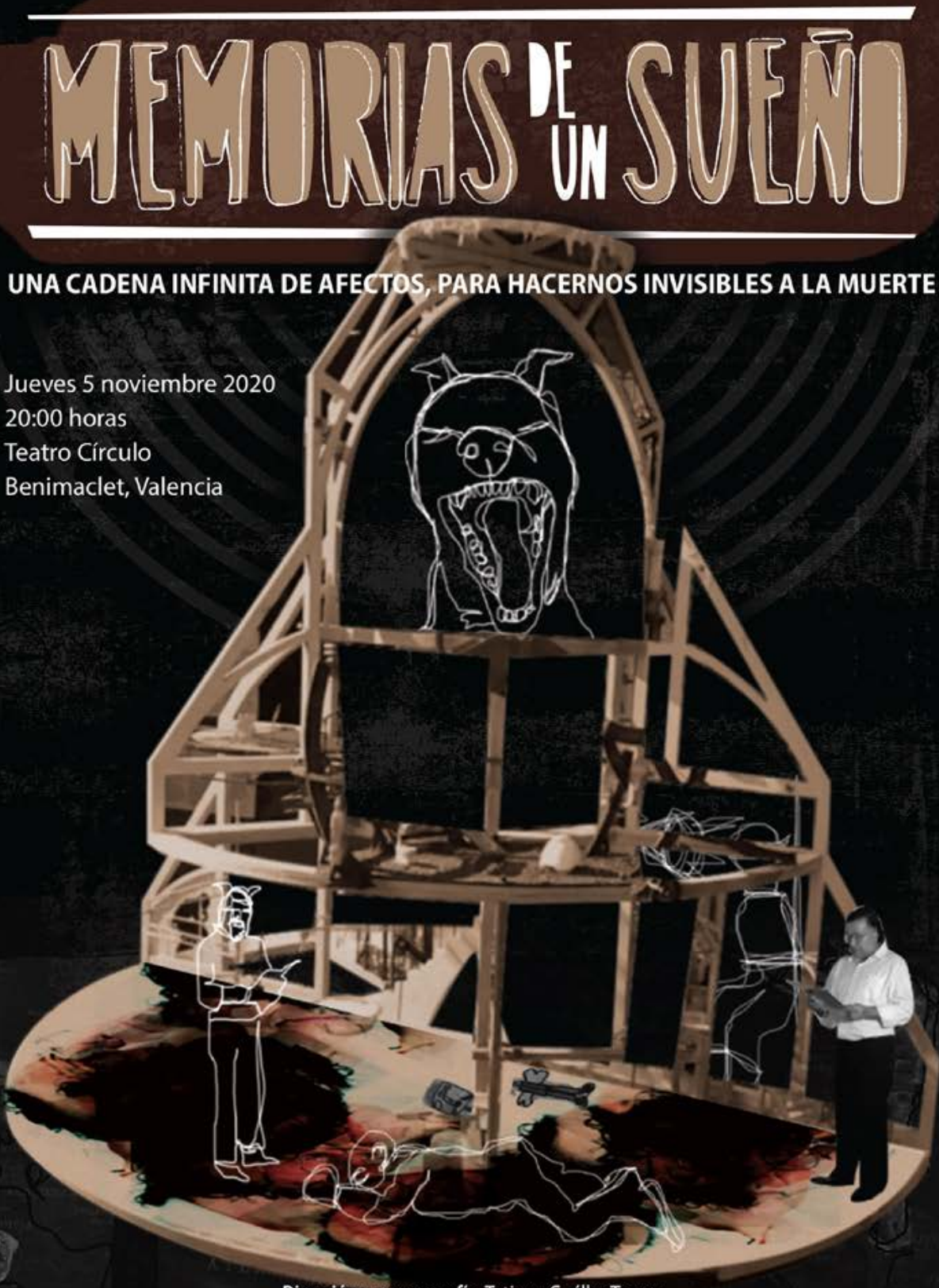

Dirección y escenografia: Tatiana Cuéllar Torres

Protagonista: Carlos Cuéllar Rivera - Intérpretes: Tatiana Cuéllar y Amélie Dussán

Producción Escenográfica: Catalina Zuloaga, Daniela muñoz Noriega, María Mas Prieto, Maria Teresa Carrión, Marta Cazalla Muńoz, María Roig, María Lara Sánchez, Sara Hernandez Rueda y Tatiana Cuéllar Torres Sonido: Carlos Julián Cuéllar y Judith Roger Esteve - Vestuario: Ana Paola Sánchez y Aina Duch Maria Cámara y edición: Carlos Clavijo - Asesoría artística: Beatriz Herráiz y Martina Botella

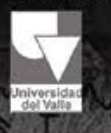

TIM UNIVERSITAT 6.j- POLITECNICA

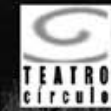

Figura 13. Identidad visual diseñada en co-creación con Kelly Gómez. Fuente: Elaboración propia. 


\section{Identidad visual}

La identidad visual de la obra está relacionada con esa maqueta efímera que se ha construido como refugio y como casa, además de ser habitada tanto por el protagonista de la historia como por los fantasmas que la habitaron. El logotipo se utiliza como mancha y contraste, en dos colores que representan la tierra, tanto la fértil como la estéril del territorio y de la memoria (figura 13).

\section{Dosier}

Este dosier apoya y complementa la información de la identidad visual de la obra como formas de divulgación y construcción de sentido visual en toda la propuesta (figura 14)

\section{Conclusiones}

Figura 14. Dosier diseñado por la autora.

Fuente: Elaboración propia.

$\Lambda$

$\Lambda$
Podemos concluir sobre la hipótesis central de este trabajo que esta propuesta es necesaria como catarsis y rompimiento de un pacto de silencio familiar, para llegar a acuerdos en medio del disenso tanto de los recuerdos más minúsculos como del imaginario colectivo que se tiene en Colombia sobre el conflicto armado.

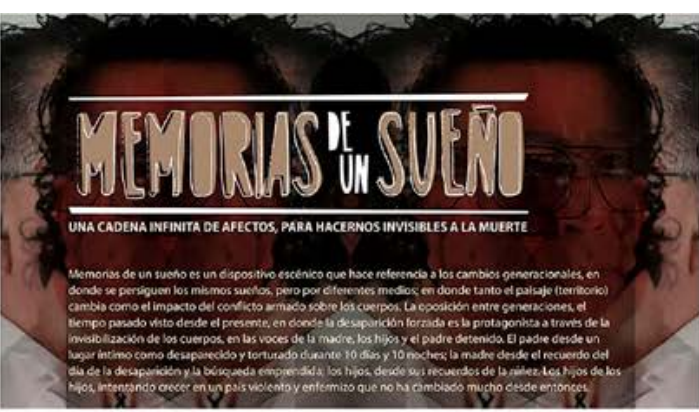

EL TIEMPO Y LA MEMORIA

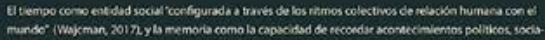

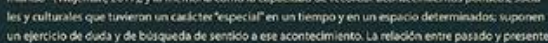

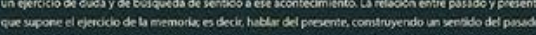

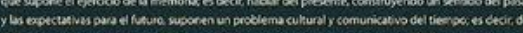

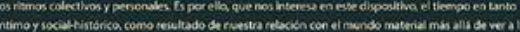

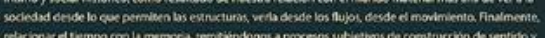

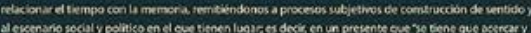

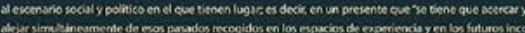

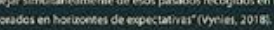

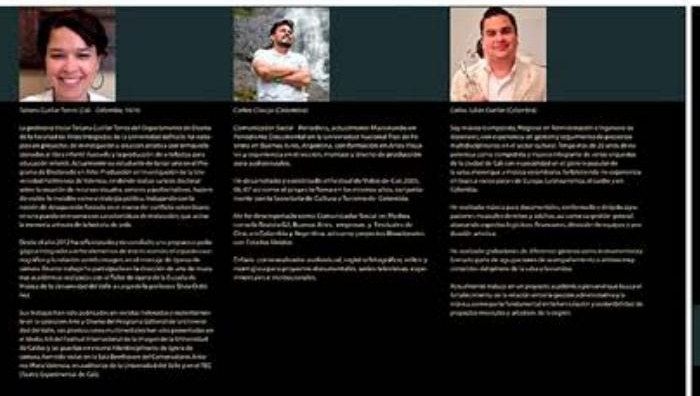

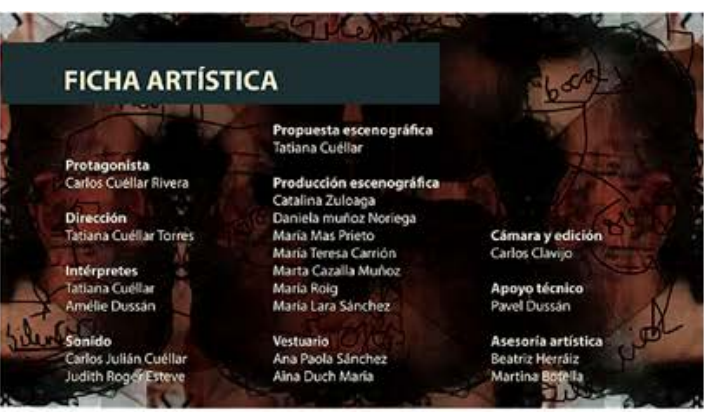
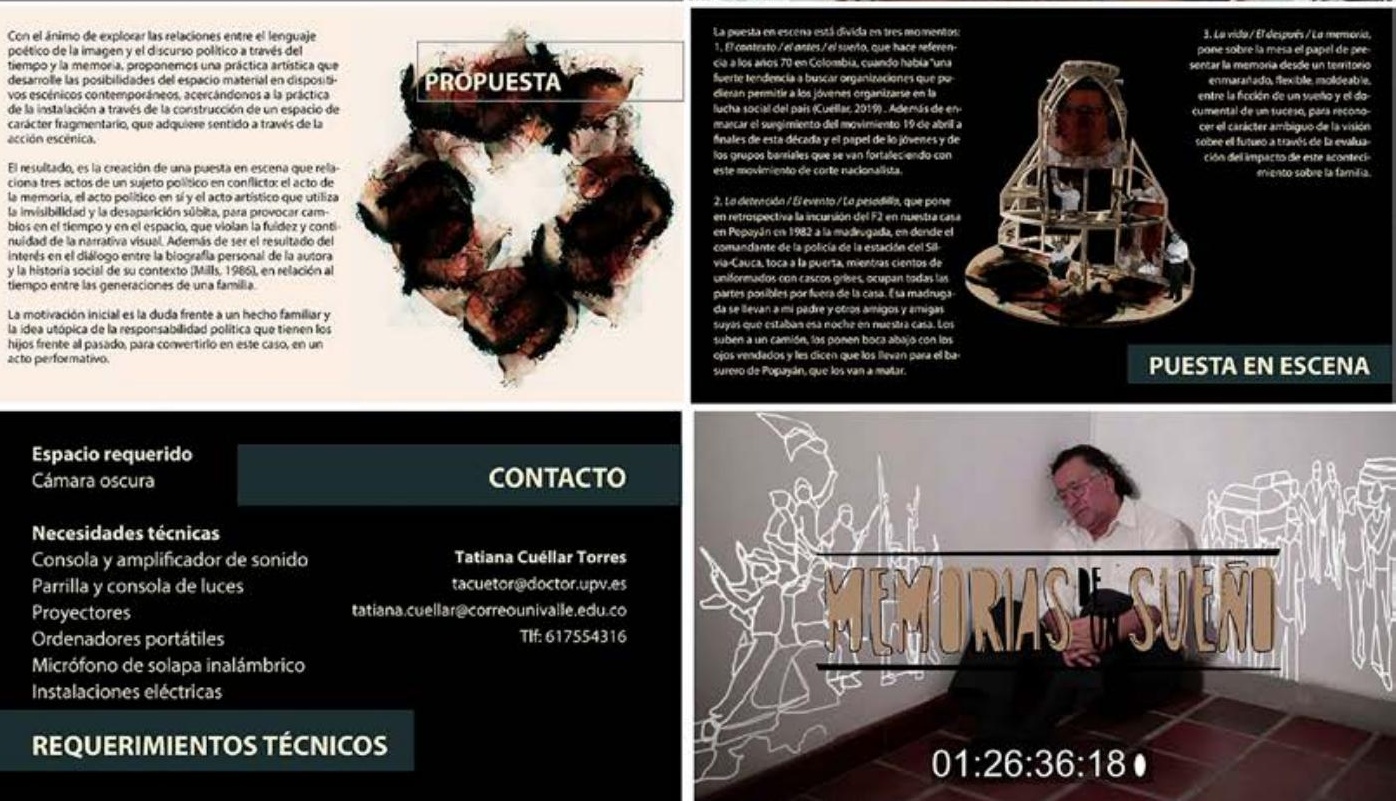

Espacio requerido Cámara oscura

CONTACTO

Necesidades técnicas

Consola y amplificador de sonido

Parrilla y consola de luces

Proyectores

Ordenadores portátiles

Micrófono de solapa inalámbrico

Instalaciones eléctricas

REQUERIMIENTOS TÉCNICOS
Tatiana Cuéllar Torres tacuetoredoctor.upv.es tatiana.cuellarecorreounivalle.edu.co Tif: 617554316 
Igualmente, que, entre los documentos institucionales y personales revisados, existen configuraciones del "yo" y del "otro" dispares entre sí, que la idea de reconciliación es remota y que el fantasma del enemigo está al servicio de la violencia como discurso político de unos cuantos. Sin embargo, que este escenario nada alentador nos permite buscar un desplazamiento en el discurso histórico y artístico, y poner los focos en el lugar de lo que ha estado oculto.

Es en esta misma línea y en respuesta a la segunda tesis que, al igual que la ambigüedad del contexto es latente, el proceso creativo es también divergente, pero que los dos van en búsquedas de consensos que nos permitan seguir habitando un espacio contradictorio, destruido y en ruinas, a través de la materialización de imágenes, sonidos y cuerpos que componen un solo espacio, un espacio de tejidos paradójicos y de cuerpos maltratados, como lo es Colombia. Asimismo, que todos los materiales visuales que se han creado para ello son un reflejo de que mi "yo" es configurable gracias al reflejo que veo en la otredad, que el trabajo creativo que inició en solitario y que termina en colectivo se ha visto enriquecido tanto en el proceso como en el resultado gracias al trabajo colaborativo realizado con las estudiantes de la asignatura de Práctica Escenográfica en el periodo académico 2019-2020, periodo que se vio afectado por el estado de alarma por crisis sanitaria covid-19 en España. Sin embargo, este trabajo de apoyo creativo y de producción realizado durante el confinamiento ha sido fundamental para marcar la práctica escenográfica de la propuesta y dar seguimiento a su producción material, audiovisual y sonora.

En referencia con la cuarta tesis, podemos concluir que la relación entre posnarrativo y posdramático hace alusión a un momento contemporáneo en el que el diseño como disciplina de la imagen y las artes vivas encuentra lugares comunes entre el audiovisual y el espacio, entre lo performativo y el movimiento de la imagen, que no tienen fronteras claras, que se encuentran entre bordes difusos y que, por tanto, se conjugan en diferentes tipos de propuestas audiovisuales y performativas como en el teatro de los sentidos, en el cine del cuerpo, en el diseño contemporáneo y en el arte contemplativo. En este campo expandido, donde hay una especie de finalidad sin fin en la creación artística, la metodología, los métodos y las técnicas de investigación basadas en la práctica artística transitan por lugares cada vez menos limitados, entre campos disciplinares amplificados, al igual que los procesos y las representaciones de la realidad, en un continuo poner al día, en una permanente adaptabilidad, entre la multiplicidad y simultaneidad de lo contemporáneo, que se democratiza en la era digital, para decantar distintos usos de la imagen: industriales, de entretenimiento, de creación artística, de entorno académico, etc., donde compartimos un campo de experimentación común, sin importar nuestro territorio disciplinar.

Finalmente, en respuesta a la primera y tercera tesis, que la desaparición forzada es posnarrada desde el lugar de la memoria, la autobiografía, el documental y la ficción como estrategias que involucran al espectador desde un acontecimiento individual hacia una referencia colectiva de búsquedas y problemas sociales, de sueños y emociones expuestas desde el recuerdo y la ficción de las imágenes y los sonidos, el cuerpo y el espacio. 
[NOTAS]

1. Véase sitio web https://www.mapateatro.org/es.

2. Véase sitio web https://atirohecho.wordpress.com/.

3. Véase sitio web https://www.youtube.com/watch?v=CAX75K0xkPs.

4. Véase sitio web https://www.annaviebrock.de/.

5. Véase sitio web https://www.fundacionjumex.org/es/exposiciones/39-cosmogoniadomestica-damian-ortega.

6. Véase sitio web https://www3.mcachicago.org/2015/salcedo/works/la_casa_viuda/.

7. Véase sitio web https://miprimerdrop.wordpress.com/portfolio/tierras-del-sud/.

8. Véanse sitios web:

https://www.youtube.com/watch?v=MkjPliiOWD8\&feature=youtu.be https://www.youtube.com/watch?v=NWWHKRx-00Y\&feature=youtu.be https://www.youtube.com/watch?v=|Bc3XFIBR2s\&feature=youtu.be https://www.youtube.com/watch?v=JWtvYDijYCk\&feature=youtu.be https://www.youtube.com/watch?v=-pzbDm0KOHc\&feature=youtu.be https://www.youtube.com/watch?v=PRX8-rtfh40\&feature=youtu.be.

9. Véanse sitios web:

https://www.youtube.com/watch?v=9uSQDanKv1U https://www.youtube.com/watch?v=D7nNgnnboFE https://www.youtube.com/watch?v=HD23-188-mk https://www.youtube.com/watch?v=e6HzUDZgejl https://www.youtube.com/watch?v=9jkmvprj26Y https://www.youtube.com/watch?v=BdC3xUImeYc https://www.youtube.com/watch?v=GOVykcSeXqw https://www.youtube.com/watch?v=1DhhPM6Y558 https://www.youtube.com/watch?v=EfUkCN_nE-A https://www.youtube.com/watch?v=uptSw3vzlWE https://www.youtube.com/watch?v=9s0vN7iVE5E\&t=73s https://www.youtube.com/watch?v=G5pJ0y-hkhY https://www.youtube.com/watch?v=lem_xlqENf4 https://www.youtube.com/watch?v=liT90p8gNSQ https://www.youtube.com/watch?v=iMXfmI7IALw. 


\section{[REFERENCIAS]}

Arfuch, Leonor. 2002. El espacio biográfico: Dilemas de la subjetividad contemporánea. Buenos Aires: Fondo de Cultura Económica.

Arfuch, Leonor. 2013. Memoria y autobiografía: Exploraciones en los límites. Buenos Aires: Fondo de Cultura Económica.

Bachelard, Gaston. 2000. La poética del espacio. Buenos Aires: Fondo de Cultura Económica.

Breyer, Gastón. 2005. Escena presente: Teoría y metodología del diseño escenográfico. Buenos Aires: Infinito.

Constitución Política de Colombia. 1886. Colombia. Consultado: 3 de noviembre de 2020. http://www.suin-juriscol.gov.co/viewDocument. asp?id=1826862

De Blas, Felisa. 2006. "Espacio y teatro". Acotaciones 16: 1-28. Consultado: 3 de noviembre de 2020. https://www.resad.es/acotaciones/ acotaciones16/16felisa.pdf

Grabe, Vera. 2010. "M-19: De la lucha armada a la renuncia a la violencia”. En IV Jornadas internacionales sobre terrorismo los finales del terrorismo: lecciones desde la perspectiva comparada, 1-33. Fundación Manuel Giménez Abad de Estudios Parlamentarios y del Estado Autonómico. Consultado: 3 de noviembre de 2020. https:// dialnet.unirioja.es/servlet/libro?codigo=662715

Méndez de Vigo y Montojo, Î̃igo. 2017. "La paradoja teatral de Kentridge". En William Kentridge: Basta y sobra, 2-3. Madrid: Museo Nacional Centro de Arte Reina Sofía. Consultado: 3 de noviembre de 2020. https://www. museoreinasofia.es/publicaciones/william-kentridge-basta-sobra.

Muñoz Fernández, Horacio. 2017. Posnarrativo: El cine más allá de la narración. Santander: Shangrila.

Ospina, William. 2019. "Estamos cansados". El Espectador, 1 de diciembre de 2019. Consultado: 10 de marzo de 2020. https://www.elespectador. com/opinion/estamos-cansados-columna-893621/.

Racière, Jaques. 2005. Sobre políticas estéticas. Barcelona: Museu d'Art Contemporani de Barcelona.

Salvi, Valentina. 2018. "Desaparición forzada”. En Diccionario de la memoria colectiva, dirigido por Ricard Vinyes. Barcelona: Gedisa.

Sánchez Gómez, Gonzalo. 2014. "Presentación”. En Normas y dimensiones de la desaparición forzada en Colombia, 17-18. Bogotá: Centro Nacional de Memoria Histórica. Consultado: 10 de marzo de 2020. http://www. centrodememoriahistorica.gov.co/micrositios/desaparicionForzada/ libros-tomo1.html

Wajcman, Judy. 2017. Esclavos del tiempo: Vidas aceleradas en la era del capitalismo digital. Barcelona: Paidós. 